\title{
Editorial: \\ Chabani Manganyi's memoir
}

[ B R I E F I N G S ]

Chabani Manganyi's memoir, Apartheid and the making of a Black psychologist, was launched in June this year, at Circa Gallery in Rosebank, Johannesburg. The invited speaker at this event was Grahame Hayes. Wits University Press then organised another launch event, in conjunction with WiSER (Wits Institute for Social \& Economic Research), and the Department of Psychology, which was held at WiSER on 24 August 2016. The speakers at this event - Catherine Burns (WiSER), Garth Stevens (Dept of Psychology - Wits), and Hlonipha Mokoena (WiSER) - were asked to discuss Manganyi's memoir under the rubric, "Being black in the world: Race, memory and the psychology of Black subjectivity in the memoir of Chabani Manganyi".

The purpose of this brief editorial note is to explain the rationale for the inclusion of the seven short contributions on Manganyi's memoir that follow in this section entitled, "Briefings: Launching Chabani Manganyi's memoir". After the first launch event, on 25 June 2016, PINS (Psychology in society) decided to review Manganyi's memoir in a slightly different way from our usual book reviews. Given the importance, and under-appreciated, legacy of Manganyi's ideas and work in the history of South African psychology, we thought it would be interesting to get a range of reviewers to respond to his memoir. To this end PINS approached three people to review Apartheid and the making of a Black psychologist - two of them (Kessi Shose \& Kylie Thomas) are relatively young academics at the beginning of their careers, and the other (Anthony Pillay), is an established mental

\section{Grahame Hayes}

University of KwaZulu-Natal Durban

grahame.hayes@gmail.com 
health practitioner and academic who has had an interest in Manganyi's work over many years.

While Chabani Manganyi positions himself as a psychologist, he is also much more than this, as is borne out by the interest shown in his work from historians, literary theorists, and social scientists. Fortunately, two of the speakers (Burns \& Mokoena) at the WiSER launch event in August are historians, the former being an historian in, and of, the medical humanities, and the latter an intellectual historian (see for instance her book Magema Fuze: The making of a Kholwa intellectual, 2011). So together with Garth Stevens, PINS thought that these two speakers would offer a slightly different perspective on Manganyi's memoir, and broaden the scope of the responses beyond the disciplinary confines of psychology. PINS, thus approached Catherine Burns, Hlonipha Mokoena, and Garth Stevens to contribute their talks ${ }^{1}$, from the WiSER launch, to this issue of the journal. Finally, it was also decided to include Grahame Hayes' talk from the June 2016 launch, as this contribution gives some historical contextualization to the work and ideas of Chabani Manganyi.

So what follows in this focus on Manganyi's Apartheid and the making of a Black psychologist, are seven short papers, in historical order: Hayes (June 2016 launch); Burns, Mokoena, and Stevens (August 2016 launch at WiSER); and Shose, Pillay, and Thomas (commissioned book reviews). PINS hopes that these contributions allow readers to engage with the multiple voices that Manganyi speaks with, and how these voices are heard in different and fascinating ways by a diverse community of scholars.

\footnotetext{
Burns, Mokoena, and Stevens have all revised their original talks for this issue of PINS.
} 